\title{
Environment-friendly roads
}

\author{
Anna Leniak-Tomczyk ${ }^{1}$, Grażyna Lagoda ${ }^{2}$ \\ ${ }^{1}$ DrogMost Lubelski Sp. z o.o., ul.Wrotkowska 1b, 20-469Lublin,e-mail: anna.lt@drogmost.pl \\ ${ }^{2}$ Instytut Dróg i Mostów, Wydział Inżynierii Lądowej, Politechnika Warszawska, \\ e-mail: g.lagoda@il.pw.edu.pl
}

\begin{abstract}
Road schemes are linear in nature, which makes the investment process exceptionally difficult and complex, requiring the involvement of large human potential, time-consuming and very expensive. One road investment is subject to numerous consultations, requires many different studies, collecting a huge amount of opinions as well as approvals and obtaining a number of decisions. Currently without including in the project some solutions that would both guarantee minimal influence of the investment on the environment and ensure the efficiency of local ecosystems it is impossible to obtain the positive decision concerning the condition of the environment, which would allow the realisation of the project. An engineer of the 21 st century apart from providing the right construction of a given structure, which ensures that this structure is secure, functional, resistant and has architectural merit, must also take into consideration local environmental conditions. The engineer has to ensure that the environment may function without any obstacles and the species may migrate without restraint. To do this, an engineer needs to have clear guidelines concerning both the project and its realisation. The article contains the general form of these guidelines.
\end{abstract}

Keywords: Roads; Environment protection; sustainable development.

\section{Introduction}

The process of creating a transport route in Poland requires performing formal and legal actions in the appropriate order, in accordance with the legal acts, regulations and notices in force. In addition, the investment process of roads and bridges construction is governed by separate provisions, such as e.g. technical standards or orders of the General Director of the National Roads and Motorways. Many studies regulating certain issues related to the process of road creation are also issued. These are auxiliary studies (it is not obligatory to apply them) issued by the Ministry of Infrastructure and Development, Ministry of the Environment or the General Directorate for National Roads and Motorways. The complete procedure in the investment and construction process related to road creation covers in general as per design team of General Directorate for National Roads and Motorways (GDDKiA) [1]:

- process preparation, including:

o the preliminary design phase (network study: SS);

$\circ$ the phase of obtaining administrative decisions:

- design studies necessary to obtain the decision on environmental conditions (corridor study with multicriteria analysis - SK; technical, economic and environmental study - STES; materials to the decision on environmental conditions - DSU); 
- design studies necessary to obtain the decision on the permission to implement a road project (geodesic and cartographic studies - MDCP as well as formal and legal studies; road preliminary design - KP; building permit design - PB; materials necessary to obtain the decision on the permission to implement a road project - ZRiD);

$\circ$ the phase of complementary and final design:

- post-construction audit of road traffic safety,

- environmental protection studies (report on implementing the provisions of the environmental approval; post-implementation analysis; ecological review);

- documentation for notification of the works; tender documentation, including the documentation for the "design and build" system;

o the phase of obtaining investment funds from external sources:

- feasibility study together with the results, including the cost benefit analysis;

- process implementation covering:

o construction and assembly works (including production of construction materials);

$\circ$ acceptance and handover.

The process of creating transport engineering structures in the 21 st century requires that the participants to this process demonstrate a largely innovative approach. This process should include, apart from the technical and purely engineering side, also the aspects related to the concern for the environment and wildlife, as well as aesthetic and economic aspects. Such solutions should be related to the widely understood environmental protection, covering also obtaining renewable energy, which enables return of construction costs in a relatively short time.

\section{The issue of laying out transport routes on examples}

In our country laying out a new transport route (in particular of a new expressway) is related to a number of problems. The first one is the decision whether the implementation is to be carried out along the "new course" or along the old route. Over the years the existing national, province, district and commune roads have become surrounded by houses, homesteads and services-related facilities. Laying out a new road along the "old course" in the majority of cases will in fact require destroying many structures, even entire villages, which will result in many protests and considerable damage. Building a new road and occupying new land for the road lane is in turn related to the loss of agricultural land, deteriorated farms layout, which results from laying out transport routes running through the fields and separating the fields from residential areas, or to lowered quality of soils surrounding the transport route. Apart from occupying agricultural lands to be used directly underneath the route, the production capability of lands situated in the vicinity of the road is reduced (this is related to environmental pollution caused by exhaust fumes), even by one valuation class. This may lead to protests of individuals or even of whole communities against the route of a given road. Since approximately $38 \%$ of our country is covered with environmentally valuable areas (including the areas protected under the Act on the Environmental Protection and the areas which are covered by Nature 2000, as well as the areas where the habitats and species protected under the Council Directive 79/49/EEC [2] and the Council Directive 92/43/EEC [3] are situated) and at the same time our country is largely agricultural, laying out roads circumventing agricultural lands will direct the roads 
towards protected or developed areas. In the first case it will cause protests of the local environmental societies or environmental organizations (NGOs) and in the second case protests of the society.

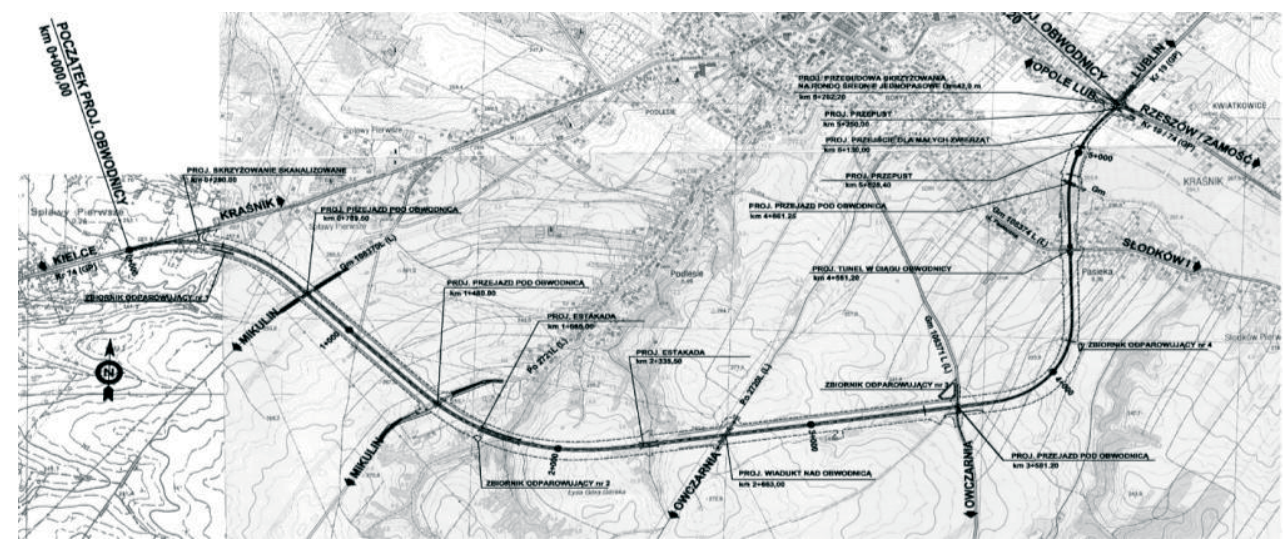

Fig. 1. The variant of laying out Kraśnik circular road the variant selected in 2006 for design and construction (stages $\mathrm{PB}, \mathrm{PW}$ )

The author experienced the protests of local environmental societies in the process of construction of Kraśnik ring road (Kraśnik is a town in south-eastern part of Poland, in lubelskie voivodship) within the national roads No 19 and No 74 [4]. In the discussed Kraśnik ring road example the environmental communities reported unofficial comments as to the route of the ring road. Therefore in 1986 in the preliminary design the selected route was located on the edge of the area described as "protected in terms of landscape". Since in later years the boundaries of the Kraśnik Area of Protected Landscape were expanded and the ring road route was moved towards Kraśnik (and included in the local area development plans), the environmental communities of Lublin area strongly protested against laying out this road in such a way. What they mainly protested against was that the route goes through: environmentally valuable groups of gorges, a group of 5 ponds, groups of one of the most valuables orchid localities in the macroregion, ecological site of Krasny stream and Wyżnica river, spring area of Wyżnica river and the area of protected groundwater. In the end the ring road was designed taking into account all the environmental, administrative and social issues. Even though it goes through environmentally valuable areas, on 22 May 2007 it obtained the environmental approval. Kraśnik ring road was constructed and handed over in November 2010.

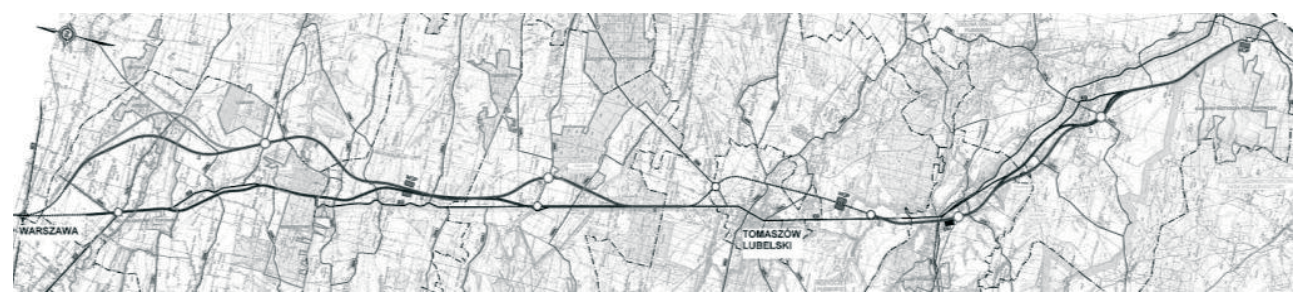

Fig. 2. Laying out the S17 expressway between Zamość and Hrebenne in difficult social and environmental conditions (stages KP and STES). 
The author came across the protests of environmental organizations (NGOs) and protests of local communities while preparing Preliminary Design and STEŚ together with the report on the environmental impact for the (Warsaw) Zakręt - Lublin - Zamość - Hrebenne (Lvov) section of S17 expressway at the Zamość-Hrebenne (border of Poland) section. The Preliminary Design was started in 2006, the report on the environmental impact was prepared together with successive annexes, updates and redrafts between 2007 and 2013. Until present (March 2016) the environmental approval for this investment has not been issued. Among the reasons for this are: amendments to the legal provisions, creation of Nature 2000 areas and changes to their boundaries, protests of ecologists, including NGOs, and social protests. There is a chance that around the end of the current year the investment will obtain its environmental approval.

\section{Innovative solutions in transport infrastructure engineering on examples}

As the ancients used to say, "Conservatio est Aeterna Creatio" (preservation is eternal creation). One of the spectacular implementations of this maxim are the designs sent to the international competition "Solar Park South" for the use of one section of Del Sole Highway (A3 Salerno - Reggio Calabria Highway) which is being removed from use. The highway section being closed, between Bagnara and Scilla, was constructed in 1960-1970 mainly on viaducts and tunnels. Highway del Sole runs through a very attractive region in terms of landscape and tourism, as seen on picture 8. On one side there is a landscape with the mountains and local villages and on the other the Mediterranean Sea, Calabria coast, Messina strait, Sicily and Lipari Islands.

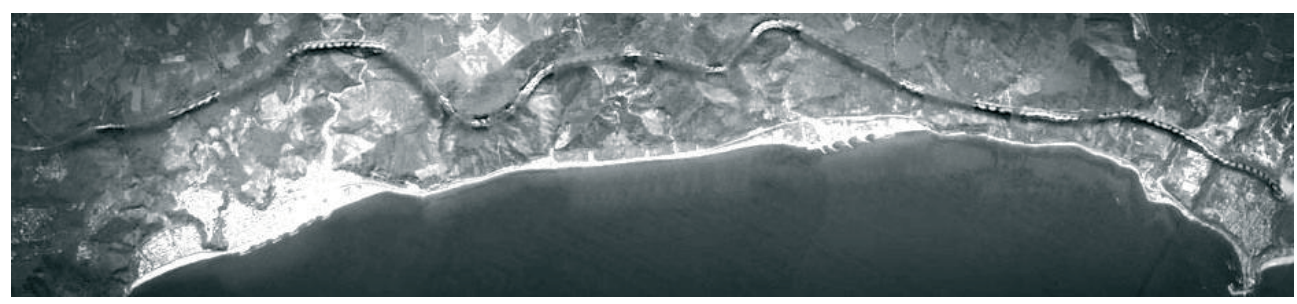

Fig. 3. The course of del Sole Highway on the Calabria coast ${ }^{1}$

The rules of "Solar Park South" competition state that one line of the highway (southnorth) is to be devoted to create a place to test generating energy from renewable sources or to search for new sustainable technologies. The second line of the highway would constitute a section of national road No 18 aimed at ensuring better communication between Scilla and Bagnara communes, including integration of the existing A3 road with the surrounding landscape, elements of the environment and buildings, local communities with tourists, the surrounding mountain and village areas, taking into consideration eco-development and using service roads and technical elements left after the construction of the new section of Highway del Sole. 1 visualisation by: Francesco Colarossi, Giovanna Saracino, Luisa Saracino - upon Francesco Colarossi's consent
received via e-mail 


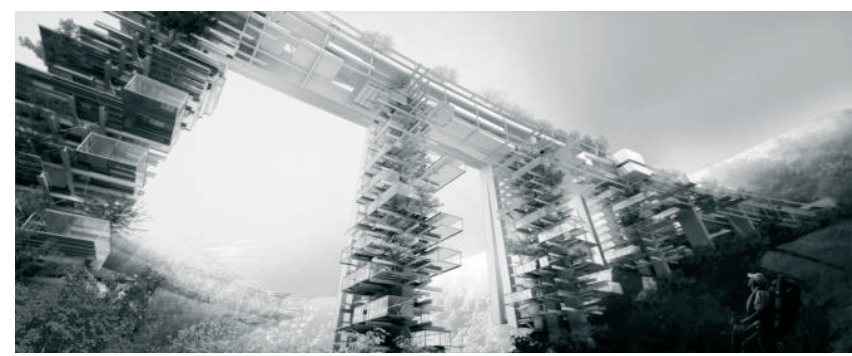

Fig. 4. The design prepared by the French: first prize at the Solar Park South competition in Calabria ${ }^{2}$

Here are the designs which came first, second and third in the competition. First prize (Fig. 4) went to the design prepared by the French: Philippe Rizzotti, Vermet Tanguy, Manal Rachdi, Samuel Nageotte; it is an autonomous system based on the rainwater and geothermal energy, constructed from vertically situated apartments, as well as shops, medical and entertainment facilities, which also enables climbing, skiing and other sports, using all the aspects of this region.

Second prize (Fig. 5) was awarded to the design by the Italians: Francesco Colarossi, Giovanna Saracino and Luisa Saracino. Its name is Solar Wind Bridge and it is based on using the existing viaducts along the A3 highway in Calabria for continuous generation of energy with the use of hybrid system combining solar and wind energy. The project is based on the idea of using the space between the pillars of the existing viaducts to assemble a system of wind turbines which will be incorporated in the entire structure. The second idea of the Solar Wind Bridge design is the so-called solar park, approximately $20 \mathrm{~km}$ long, on one carriageway. The solar park is conceived as "green" promenade, similar to panoramic greenhouses, entirely self-sufficient in terms of energy and heat. The park guests will be able to rest and walk along the promenade, admire amazing views of the Calabria coast, the sea, nearby islands etc., buy local products grown in such greenhouses: vegetables, fruit, corns, garden plants etc. The third idea of Solar Wind Bridge is replacing asphalt of the other carriageway, approx. $20 \mathrm{~km}$ long, with the so-called "solar roadways" (it consists in replacing asphalt on the A3 road surface with specially prepared solar cells which can withstand loads and are highly resistant: half-transparent layer consisting of solar cells, LED lamps and heating elements, electronic layer to control the lighting and communication and the basic layer which separates the electrical wiring system of the road from the local electrical wiring system).

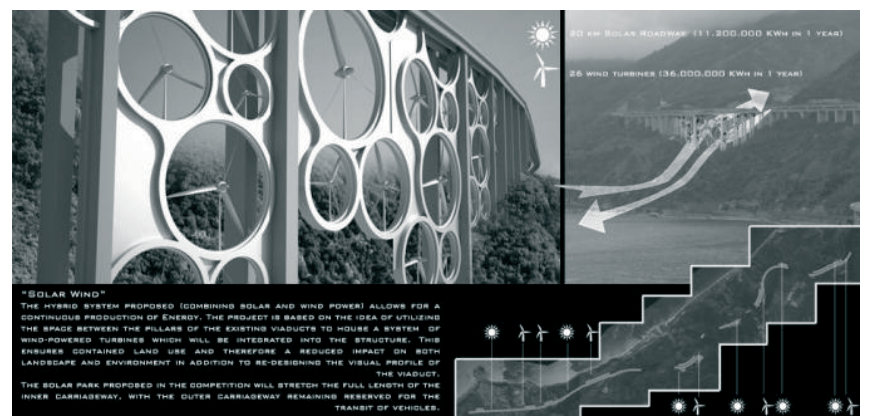

Fig. 5. The second prize at the Solar Park South competition in Calabria - a view of wind turbines ${ }^{3}$

2 source: www.newitalianblood.com/solarparksouth/projects/494-1.html; accessed on: 02 December 2013 
Third prize (Fig. 6) went to the design prepared by the Colombians: Daniel Azuero, Tomas Jaramillo, Andres Gutierrez, Juan Jaramillo. The idea here is "green education". The design instructs that the civic activity of the local communities combined with using materials and crops from a given area is the key to success. The design encourages the locals to participate in the construction by creating the common area, so-called Green Education Research Centre, which everyone can enjoy. This is to serve an example to other regions around the world of how to use, in a sustainable way, a structure existing in a given region by promoting it and deriving profit from it [5].

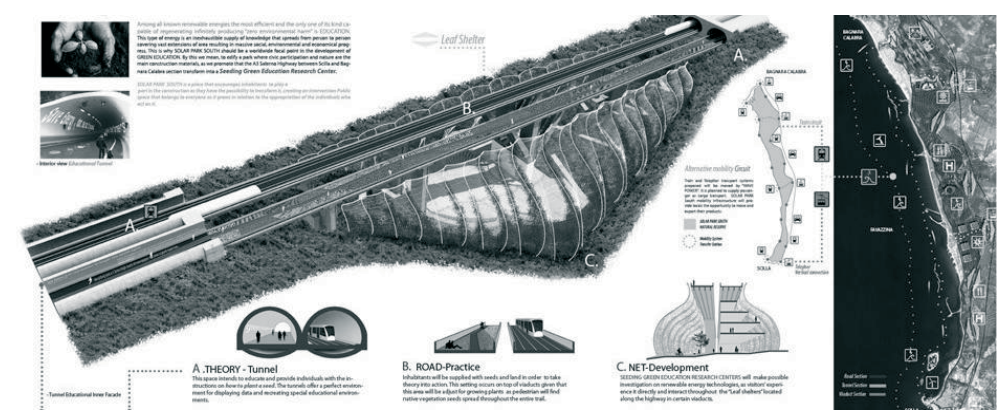

Fig. 6. The design prepared by the Colombians: third prize at the Solar Park South competition in Calabria ${ }^{4}$

\section{The guidelines for creation of transport engineering structures in the spirit of eco-engineering}

\subsection{Design of environmental protection structures}

From April 2002 to June 2009 when designing national roads in Poland "Catalogue of road facilities for environmental protection", which constitutes an annex to the Order No 58 of the General Director of National Roads and Motorways, was applied [7]. It has been withdrawn and until now no other document has replaced it. The legal provisions do not offer any definition of "facilities for environmental protection". For the purposes of the article we will assume, following the out-of-date "Catalogue of road facilities for environmental protection", that among the types of facilities for environmental protection, that is the structures used for environmental protection within the road right-of-way, are: noise barriers, facilities for waste water disposal and treatment, fencing for animals, passages for animals, tunnels and security coverings, protective greenery; however, due to limited amount of space only some of them will be discussed in the article.

The developed areas, leisure and recreational areas outside of the city, hospital areas outside of the city, health resort protection areas: they all have their established permissible levels of noise in the environment caused, among other things, by traffic (regulation on the permissible levels of noise in the environment). When a transport route runs through one of the aforementioned areas and if the relevant calculations show that the permissible values of noise are exceeded, the permissible level must be retained within the road limits. One of the ways to limit the noise which exceeds the standard level is to use noise barriers. A noise barrier has undoubtedly many features such as: it occupies small area, is easy to assemble,

\footnotetext{
3 as above

4 source: www.newitalianblood.com/solarparksouth/projects/80-1.html; accessed on: 02 December 2013
} 
has good efficiency and acceptable costs. Due to their acoustic properties such barriers are divided into: reflecting, which reflect the sound wave towards the source e.g. from acrylic plates; reflective/diffusive, which have additional diffusive features in the form of pits and recesses; absorptive, which are shaped in such a way as to increase their absorptive properties, are filled with absorptive materials and have the possibility to be covered with climbing plants. In terms of the material which the barriers are made of we divide them into: metal, concrete, concrete with the addition of other components, glass, acrylic, ceramic, wooden and other. In terms of the shape of the cross-section the barriers are divided into: vertical, horizontal, suspended vertical, rectangular, wedge-shaped, trapezoid, curved. Due to the vertical projection noise barriers are divided into rectilinear and curvilinear (acoustic properties, aesthetic values, terrain conditions, removal of monotony). In terms of their assembly the barriers are divided into: segmental (assembled using large segments of catalogue size) and modular (assembled using successive elements of a small module).

Within the last years in the south-western and north-western parts of Poland noise barriers was a very popular solution. Unfortunately, after some years it has turned out that in many cases the barriers do not perform their role. Many incorrect solutions were used, the efficiency of the barriers was alarmingly low, even their aesthetic aspects in most cases left much to be desired. Therefore, in addition to the proper design a detailed analysis of the efficiency of a given barrier, in particular in the urbanised structure, should also be carried out. An improperly placed barrier is not only an additional source of shadow but the reflecting surface which modifies the acoustic field, not always to the benefit of the people living in the built-in area, in some cases also unnecessarily defaces the landscape. In order to reduce the noise similarly to a noise barrier we should plant in the same place a vegetated strip which is 5-10 or more metres wide. Moreover, it takes a long time for the trees to grow so the intended effect of noise reduction will be possible in a decade or so. It is known that in an urbanised area such space is scarce. However the greenery, apart from its anti-noise function, also performs many other roles (protects the side of the road against atmospheric pollutions, protects the soil and water, has aesthetic values) and it is a human-friendly and natural method. Instead of the barriers we can also use (whenever possible) earthen rampart planted with certain species of plants, which also serve as a noise barrier, protect against air pollution and have aesthetic values if appropriate plant compositions are used.

In terms of roadside greenery in Poland the issues which arise when building a new road differ from those occurring when e.g. the roadside trees already exist. There are many opponents to roadside trees who argue that: such trees cause many accidents, people die when crashing into such trees (around 3 people die daily and 20 are injured after crashing into a tree which grows too close to the roadside - source: www.policja.pl). However, many natural scientists and ecologists protest against cutting roadside trees (there are examples of people chaining themselves to the trees). Natural scientists urge people not to impoverish the landscapes, to preserve many valuable dendrological items (in particular in the case of cutting precious avenue trees, such as lindens or willows). Roadside vegetated strips may be a partial solution to the problems related to laying down the roads. Placing the widest possible vegetated strips at the widened (for this particular purpose) right-of-way of a road while using appropriate and variable plants (trees, not necessarily high, but also bushes or covering the ground with sod) will effectively protect the nearby agricultural areas (e.g. using two protective vegetated strips instead of one decreases the possibility of losing productive capabilities of soils which are in the immediate vicinity of the road by even $10 \%$ [4]. Vegetated buffer strips near the roads require widening the road within its limits and as a result the road occupies a larger area of land. Moreover, a certain group of natural 
scientists (e.g. OTOP) firmly oppose to such solutions since they see the road (in particular an expressway) as a danger to the animals developing in such biocenoses. In the case of mammals and amphibians this is the matter of appropriate fencing but in the case of birds there is no possibility to eliminate their confrontation with vehicles travelling on the road.

The issue of fencing for animals used near the roads is basically omitted and treated superficially, while it is very important to properly design (and then build) protective fencing. Such fencing not only prevents the animals from entering the road and being killed by the vehicles but also protects the road users against collisions with animals which may result in death or disablement of such users (in particular following a collision with medium and large animals), or, in the most optimistic scenario, damage to the vehicle.

a)
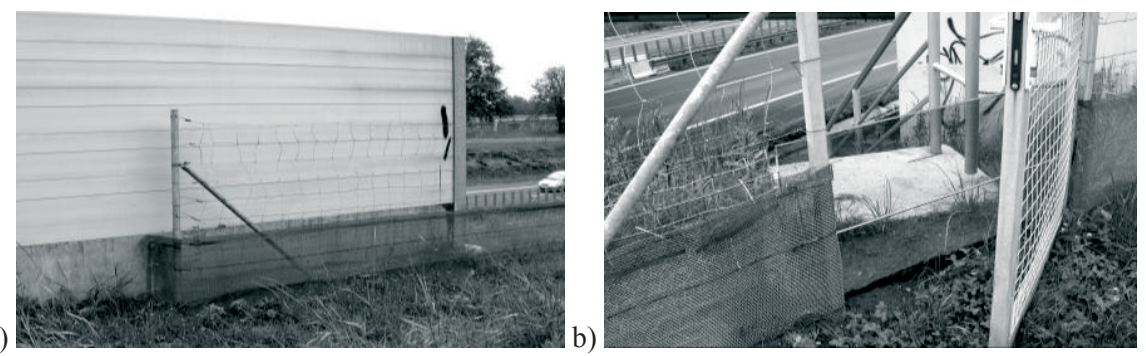

Fig. 7. Examples of proper protective fencing which effectively prevents small (e.g. amphibians), medium and large animals from entering the road (A4) (photo by A. Leniak-Tomczyk)

Examples on Fig. 7 show what protective fencing should look like: effective protection against amphibians, reptiles and mammals entering the road by using steel large-mesh netting, and additionally steel small-mesh netting and plastic netting with a freely lowered closing which will prevent the climbing fauna representatives from getting to the other side of fencing. The larger the mesh density, the better because young amphibians are very small. Near the fencing door (Fig. 7) plastic partitions should be placed. Thanks to them even if they are left partially open the small fauna representatives will not be able to go behind the fencing.

A very important element of animal fencing is placing it deep enough in the ground and connecting the netting appropriately to the engineering structure abutment, the noise barrier (Fig. 7) or the side slope. Improper placing the netting in the ground or lack of such placing may result in small animals squeezing underneath the fencing, digging under the netting, and finally (e.g. in the case of a wild boar) causing damage. Moreover, protective fencing should be appropriately connected to the system which guides the animals to the passages intended for them, without interrupting the continuity of such system. In principle natural scientists recommend natural systems of guiding animals to the passages, i.e. plant systems. Only in the case of guiding amphibians prefabricated elements or nettings are a better solution. The advantage of prefabricated elements is also that they end with a "roof" and "leg" (in the shape of inverted "L" letter) which prevents the jumping and climbing small fauna representatives from reaching the road. Nevertheless, the systems of guidance and the developed animal passages should be equipped with appropriate plant groups (the best ones being native groups). In the case of animal passages (as long as these are not complex passages) it is important to remember that people should not use such passages. A very good and natural way is to use boulders at the entrance from at least one side of the passage (Fig. 8) which in addition will be a good hiding place for smaller mammals on their way to "the other side of the road". 


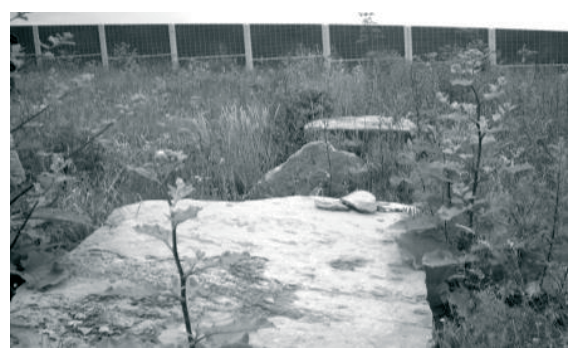

Fig. 8. Boulder rip-rap which effectively prevents small (e.g. amphibians), medium and large animals from passing through or entering the road (A4) (photo by A. Leniak-Tomczyk)

Animal passages are very important from the point of view of the whole ecosystem. If the entire road is fenced and if we do not use animal passages, we will lead to fragmentation and isolation of fauna habitats. Isolated animal populations with less than 500 animals have very little chance of survival [6].

According to the natural scientists and ecologists animal passages should be located: every $2 \mathrm{~km}$ for large animals, every $\mathrm{km}$ for medium animals, every $500 \mathrm{~m}$ for small animals, while for amphibians and reptiles (culverts) every 50-100 m on protected areas and the areas where certain species occur.

When creating animal passages the most important is their proper location which due to high cost of constructing engineering structures should be preceded by detailed analysis including both environmental and technical and structural aspects. First, the fauna habitats and ecological corridors should be marked on the map with a road section (the maps of corridors can be obtained from the book "Zwierzęta a drogi" [Animals versus roads] (by Jedrzejewski [6]) or from the website pracownia.org.pl) significant at the international and national level and information on the local migration routes should be obtained from the local natural scientists, foresters (if not, from the hunters' associations or on the basis of own knowledge and observations). After the habitats and migration corridors are marked on the map, the next step is to define the exact location of the planned animal passages with respect to the animal species living in a given location, places of the highest penetration (with the best landscape features for animal movements) and in relation to the topography and levelling of the designed road. In order for the passage to be used extensively by the animals it should be located in a place where the human activity is close to none or nonexistent, at least 200 metres from the boundaries of the places of human activity, including parking lots, crossroads, junctions and lighted road sections (including MOP, OUA/OUD, $\mathrm{SPO} / \mathrm{PPO})$.

\subsection{Location, development and organization of the base and temporary plant and facilities of the building site}

The first and basic problem at the stage of road construction is the location, development and organization of the base at the building site. This is a very complex problem since it is necessary to choose an appropriate place where it will be possible to have access to the electricity, water, waste management solutions, sewage disposal, access roads and where the entire technical and social infrastructure (place for materials storage, machines parking, concrete manufacturing facility, if necessary, and the place of stay for people) will be created. The base and the construction site also involve temporary degradation of the surrounding environment, which is particularly important in some cases where the road is to be laid out, e.g. in the area of underground water and springs protection. 
Another problem which the organizers of the construction site need to face is the access to the site and the issue of vehicle traffic organization during investment implementation. To such end the selected access roads should be optimal, giving the possibility to omit the most ecologically valuable places within the investment, and at the same time possibly short, which will not cause unnecessary emission of pollution to the atmosphere, noise emission and unnecessary fuel consumption. If possible, building temporary access roads and temporary bridge structures should be limited to the minimum because this requires additional use of materials, energy and temporary damage to the environment [8].

\subsection{On-site water balance}

Water supply at the construction sites is currently becoming more and more serious problem, both economic and ecological, due to the relation of prices and increasing tension in the balance of water sources for the people. The use of drinking water for technological purposes at the age of its significant shortage is by all means inadvisable. The contractors more and more often resort to other sources than water from water supply systems. The sources of water used for construction purposes may be, apart from the water supply systems: groundwater, surface water, mine water and atmospheric precipitations. The possibility to use the adequate sources results from the qualitative needs for the received water. The amount of water at the construction sites must be previously calculated for individual needs and closely controlled during construction in order to avoid ineffective losses. The water for potable and household use may be taken from the water supply system, underground or from cisterns and then stored, e.g. in barrels painted in black, to retain appropriate temperature without consuming additional non-renewable energy. Currently the distance to the water source or to the sewage disposal point is not a problem. Many companies offer a wide range of containers e.g. Toi-Toi, equipped with toilets, washbasins, showers, urinals, boilers, electrical heating, even containers for clean water and waste water and for faeces. These are leak free containers which prevent leakage of waste waters or other substances which are detrimental to the environment. Water may be supplied in cisterns, the issue of electricity is resolved by power generators, and the sewage is transported outside of the site to a place intended for them. In the case of construction carried out within protected areas it is a recommended solution [8].

\subsection{Environmental declarations of products}

Currently at the construction sites the legal provisions concerning EH\&S are very strict, in particular after the amendments to the Construction Law (Dz. U. (Journal of Laws) of 2006 No 156 item 1118). Such provisions regard both the issues related to the construction site, storage and type of materials used, and the works technology. Moreover, the construction works should be carried out in accordance with the Detailed Technical Specifications which constitute part of the design plans and specifications and in accordance with the provisions of the Environment Protection Law. The construction materials and products introduced to the common use must have appropriate certificates, attestations and declarations of conformity which guarantee necessary quality required by the Polish standard or technical approval. In Poland the body entitled to grant technical approvals as regards transport engineering products used only in roads and bridges construction is the Road and Bridge Research Institute. In the conditions of increasing ecological awareness, in the EU countries (including Poland) apart from technical approvals the products environmental declarations have also appeared. The products environmental declarations as an instrument used to support eco-development and eco-engineering aim at improvement of 
environmental properties of a product at the stage of production and use by indicating its ecological features and presenting them in the numerical form as appropriately selected criteria, e.g. of the impact on the environment, impoverishment of the ozone layer, greenhouse potential or acidification potential. The rules governing preparation of such declarations are included in ISO 14020 "Environmental Labels and declarations: General Principles" which covers three types of declarations: General Principles" which covers three types of declarations: Type I simplified declarations, so-called environmental labelling; Type II manufacturers' declarations, so-called own statements; Type III declarations (with appropriate verification carried out by independent institutions). Information included in such declarations regard the environmental aspects related to the production processes, also energy consumption after the product leaves the manufacturing facility and recycling of waste product. Declarations are the tools of LCA (Life Cycle Assessment) method, i.e. the summaries and assessments of the product and its potential impact on the environment in the full life cycle. The product analysis in accordance with LCA methodology includes: observation of the entire life cycle of product, from obtaining raw materials throughout their processing, product manufacturing, its use, recycling and waste management; defining all the negative environmental impacts in the full life cycle: consumption of raw materials, energy carriers, terrain, emissions to the atmosphere, water and soil, and waste materials; aggregation and assessment of such activities from the point of view of potential effects in the environment. LCA methodologies assume energy saving way of material production, higher material durability and less maintenance activities. The products manufactured in accordance with LCA methods and having environmental declarations offer ecological, technical and economic benefits [8].

\subsection{Waste management and recycling}

Using closed circuit of raw materials and construction materials is very important also due to the issue of waste. The problem of waste is one of the most serious environmental problems in the 21 st century. Even though the nature is not familiar with the issue of waste (what one organism produces becomes in nature the food for other organisms), nowadays nearly at every step we come across waste materials produced by people. The construction industry produces a lot of waste materials but many can be reused. In general in the case of repair, rebuilding or restructuring of roads many such waste materials are produced. In the case of new road construction such materials may be a by-product of road demolition at the crossroads or other conflicts with technical infrastructure. Waste materials, or rather "alternative materials", both from construction (including road construction) and from other branches of industry may be a solution to many dilemmas connected with raw materials. Problem: where to take the materials and raw materials from the shortage of which is visible today, taking into account the vision of planned expansion of roads network in our country and construction of highways would be solved at least partly [8].

\section{Conclusion}

In the 21 st century, in the conditions of global threats such as the greenhouse effect, acid rains, ozone hole, progressive degradation of the environment, complete harmonization of nature and civilization and ecological adjustment of the model of life are becoming an indispensable condition for social and economic development. This is important in particular in terms of land transportation where apart from engines improvement, search for ecological fuels or alternative possibilities of travelling, in the process of creating new 
transport routes the necessity to include and use eco-engineering solutions which go beyond the standards is becoming more and more significant. In the process of creating transport routes we should aim at protection and sustainable use of natural resources while preserving the proportions of social and economic development, including infrastructure development. We should be looking for compromise to satisfy social interests and not hinder technical development yet at the lowest possible cost to the environment. Such solutions guarantee innovative techniques and technologies, including those which take into consideration the link between the transport infrastructure engineering and the installations for obtaining energy from renewable sources. When assessing the idea of using transport engineering structures for the purpose of obtaining renewable energy we should always remember that every human activity influences the surrounding environment. Extraction of raw materials, emission of pollutants to the atmosphere, water pollution, storage of waste: these are just a few examples of activities which undeniably have a negative impact on the environment. Taking into account the signs for the future, while assuming that the road surfaces covered with solar panels will generate power and heat, that car engines will be powered with the energy obtained from the road surfaces and that, as a result of obtaining renewable energy from transport engineering structures, it will not be necessary to occupy new biologically active areas for the purpose of obtaining energy. It turns out that transport infrastructure engineering may become one of the most ecological branches of the economy.

\section{References}

1 Design team of General Directorate for National Roads and Motorways under the supervision of Wiktorowicz, K. Stadia i skład dokumentacji projektowej dla dróg i mostów w fazie przygotowania zadań (Stages and Parts of Design Documentation for Roads and Bridges at the Tasks Preparation Phase), Order No 17 of the General Director for National Roads and Motorways (GDDKiA) of 11 May 2009 as amended, Warsaw.

2 Dyrektywa Rady 79/49/EWG z dnia 2 kwietnia 1979 r. w sprawie dzikiego ptactwa (Dz. Urz. UE L 103 z 25.04.1979 str. 1, z późn. zm.).

3 Dyrektywa Rady 92/43/EWG z dnia 21 maja 1992 r. w sprawie ochrony siedlisk naturalnych oraz dzikiej fauny i flory (Dz. Urz. UE L 206 z 22.07.1992 z późn. zm.).

4 Leniak-Tomczyk A., Gazda L., Łagoda G.: Мостовые сооружения как инструмент охраны окружающей среды, Scientific International Conf. on Bridges Structured, Kiev, 2007, pp. 15-24.

5 Leniak-Tomczyk A., Łagoda G., Wiadukt w Calabrii jako przykład innowacyjnych rozwiązań w budownictwie komunikacyjnym Wiadukt w Calabrii jako przykład innowacyjnych rozwiązań w budownictwie komunikacyjnym, Budownictwo i Architektura 13(1) (2014), pp. 157-166

6 Jedrzejewski, W., Nowak, S., Kurek, R., Mysłajek, R.W., Stachura, K., Zawadzka, B. Animals versus Roads. The Methods of Limiting the Negative Impact of Roads on Wild Animals Populations, issued by Zakład Badania Ssaków Państwowej Akademii Nauk, Białowieża, 2006.

7 „Katalog drogowych urządzeń ochrony środowiska” stanowiący załącznik do Zarządzenia $\mathrm{Nr} 58$ Generalnego Dyrektora Dróg Krajowych i Autostrad, Warszawa 2002.

8 Leniak-Tomczyk A., Łagoda G. Środowiskowe uwarunkowania realizacji inwestycji drogowych w Polsce (Environmental Determinants of Road Construction Process in Poland). Instytut Badawczy Dróg i Mostów, Warszawa 2010, ISSN 1643-1618, Drogi i Mosty No 2/2010, pp. 3152. 


\title{
Environment-friendly roads
}

\author{
Anna Leniak-Tomczyk ${ }^{1}$, Grażyna Lagoda ${ }^{2}$ \\ ${ }^{1}$ DrogMost Lubelski L.L Company, e-mail: anna.lt@drogmost.pl \\ ${ }^{2}$ Institute of Roads and Bridges, Faculty of Civil Engineering, Warsaw University of Technology, \\ e-mail: g.lagoda@il.pw.edu.pl
}

Summary: The article contains the general form of guidelines within therange of interface between road engineering an environmental requirements. One road investment is subject to numerous consultations, requires many different studies, collecting a huge amount of opinions as well as approvals and obtaining a number of decisions. Currently without including in the project some solutions that would both guarantee minimal influence on the environment and ensure the efficiency of local ecosystems it is impossible to obtain the positive environmental decision. The engineer has to ensure that the environment may function without any obstacles and the species may migrate without restraint. To do this, an engineer needs to have clear guidelines concerning both the project and its realisation.

Keywords: Roads; Environment protection; Sustainable development. 
